\title{
RESOURCE COMMODITY DEPENDENCY AND STATE ECONOMETRIC MODELING
}

Fereidoon Shahrokh, Walter C. Labys, and Tom S. Witt*

\section{Introduction}

The resource dependency of national and regional economies has been a subject of substantial concern and extensive research in re cent years. This dependency has placed considerable pressure on national and regional modelers who have constructed macroeconometric models to incorporate resource behavior in their models. The national modelers were the first to respond to this challenge. In the case of developing countries where resource commodity dependence is extremely high, models have been constructed which link commodity models to national models. For example, Adams and Behrman [1982] report on model linkages which have taken place for copper and Chile, oil and Venezuela, coffee and Brazil, and cocoa and Ghana. It, thus, comes as no surprise that the present modeling effort extends the concept of commodity linkages to regional economic modeling at the state level.

This paper presents the results of a modeling study which analyzes the possible impacts of a resource industry dependency on a state economy. In this case, the resource selected is coal and the state economy is West Virginia. The basis for the study is the Commodity Regional Econometric Annual Macro Model (CREAM Model) of West Virginia, which is composed of a commodity model of the West Virginia coal industry and a macroeconometric regional model of the West Virginia state economy. The analysis performed concentrates on the linkages between the coal sector and the rest of the economy. That is, important variables influencing the coal sector are varied and the resulting impacts on the state economy are observed. These

- Economist, Virginia Electric and Power Company; Professor of Resource Economics; and Professor of Economics, West Virginia University, respectively. This study was supported in part by the Energy Research Center at West Virginia University. We would like to thank the editor and the referees of the Review for their many helpful comments. variables include changes in coal tax policies, increases in electricity generation, and recovery in steel production. The state impacts are reflected in given state economic indicators such as gross state product, general tax revenues, and employment. This paper consists of five parts: Resource Commodity Dependency, Importance of Coal in the West Virginia Economy, the CREAM Model, Model Simulation of Changes in Tax Policy and Economic Conditions, and Conclusions.

\section{Resource Commodity Dependency}

There are many economies, national and regional, which possess a heavy dependency on one or several primary commodities. These commodities can be of a renewable nature such as agricultural and forestry products, or of a nonrenewable nature such as mineral metals or fuels. Several examples of commodities and countries have been cited above. Some examples of commodities and state economies are described in Table 1; they include coal and West Virginia or Kentucky, copper and Arizona, and oil and Texas or Wyoming.

In such regions the resource commodity accounts for a disproportionate share of employment, wage income and government revenue. Because prices for these commodities fluctuate more than prices of fabricated or manufactured goods, the dependent regions correspondingly experience fluctuations in employment, income and tax revenues. ${ }^{1}$ In the last decade, we have thus witnessed an increased difficulty by state governments in dealing with the effects of the wide resource price swings which have occurred.

Although the present modeling analysis concentrates on coal and West Virginia, the methodological approach is applicable to coal and the Kentucky state economy or to other possible commodity and state economies described in Table 1.

\section{Importance of Coal in the West Virginia Economy}

West Virginia is typical of other economic 
regions whose economic development depends heavily on the existence and development of nonrenewable resources. Its coal industry generates a disproportionate share of governmental revenue, employment and wage income. Over 34 percent of the West Virginia Business and Occupation tax revenues or some $\$ 177$ million was generated directly by the coal industry in 1982. Employment in mining at 56,000 persons was approximately 9.2 percent of total state employment. Coal wage income amounted to $\$ 1.735$ billion or 14.5 percent of total wage income in the state.

The amount of West Virginia coal produced depends on national energy demand as well as national and international steel production. In recent years, the declining national energy demand has adversely affected steam coal shipments from West Virginia. Electricity generation in the United States grew by only 0.4 percent during 1980-81 and then declined by 2.3 percent during 1981-82. The decline in the national and international steel industry has also weakened the demand for coke, thereby affecting metallurgical coal shipments from West Virginia. The downturn in the coal industry resulted in an overall decline in state gross product of 5.1 percent from 1980 to 1982 while total employment fell by 5.7 percent during the same period. Similar trends continued during 1983.
This adverse impact on the state economy resulted in more interest among state economic planners in the role of the coal sector in the economic growth and vitality of the West Virginia economy. Particular attention was directed toward its economic impact on the state economy during the expansionary and contractionary phases of the national market. Major issues identified by policy planners included the following:

1. What would be the effects on the state economy of raising the Business and Occupation tax on coal? ${ }^{2}$

2. What would be the effects of increases in electricity generation in states which utilize West Virginia steam coal?

3. What would be the effects of increases in steel production by companies which utilize West Virginia metallurgical coal and coke?

4. Underlying the above is the issue of the extent to which a state tied to a primary commodity should engage in a balanced or unbalanced strategy of economic development.

\section{The CREAM Model}

The CREAM model has been particularly designed to analyze policy issues such as the above. Based on the "engine of growth" con-

Table 1

Major Resource Commodities Important for Selocted Statesa

\begin{tabular}{lc}
\hline Coal: & Copper: \\
Kentucky, West Virginia & Arizona, Utah, New Mexico \\
Natural Gas: & Iron Ore: \\
Texas, Louisiana & Minnesota, Michigan \\
Petroleum: & Lead: \\
Texas, Alaska & Montana, Idaho \\
Uranium: & Molybdenum: \\
New Mexico, Wyoming & Colorado, Arizona \\
Phosphate: & Zinc: \\
Florida, Idaho & Tennessee, Missouri \\
Potash: & Cement: \\
New Mexico, California & Texas, California \\
\hline \hline
\end{tabular}

-Stone, sand and gravel important in states that do not otherwise have a mineral resource base are omitted here.

Source: U.S. Bureau of Mines, Minerals Yearbook, 1981, Vol. II-Domestic, Washington, D.C.: U.S. Government Printing Office. 
cept, the model extends the econometric approach suggested in Adams and Behrman [1982] to explain the impact of the West Virginia coal industry on the surrounding economy. Since the theoretical specification underlying the model can be found in Shahrokh and Labys [1984], we present only a brief summary of its main characteristics. The overall structure of the model has been specified in Figure 1 which includes detail on the coal model, the state econometric model, and their linkages. The combined CREAM Model consists of 66 behavioral equations and 57 identities. It takes 29 exogenous variables from the U.S. economy and has 123 endogenous variables. Each of these models is described separately and then the linkages explained.

\section{The Commodity or Coal Industry Model}

The commodity model of the West Virginia coal industry takes into consideration coal production, prices, wage rates, average labor productivity and employment by method of mining. Shipments of coal by end-users are modeled according to receiving regions in the United States and to importing regions abroad. The specification of the model as shown in Figure 1 follows from that of the general theory of commodity model formulation, as described in Labys [1973] or Labys and Pollak [1984].

The demand for West Virginia coal has been divided into four different end-user classes: (1) electric utilities, (2) coke plants, end-user class (k), (3) other industries, and (4) retail. This demand may originate in many states as well as in foreign markets. The states of importance have been grouped into three regions according to the Department of Energy classification. (1) New England, Middle Atlantic, East North Central, West North Central; (2) South Atlantic (except for West Virginia), East South Central, West South Central; and (3) West Virginia. Three demand functions are estimated for each region (i).

$$
C D_{t}^{i k}=f\left(F P_{t}^{i k}, C P R R_{t}^{k}\right)
$$

where

$$
\begin{aligned}
& \mathrm{CD}_{\mathrm{t}}^{\mathrm{ik}}=\text { demand for W. Va. coal by con- } \\
& \text { suming class }(k) \text { in region } i \\
& F P_{t}^{i k}=\text { final coal product by class }(k) \text { stem- } \\
& \text { ming from region } i \\
& \mathrm{CPR}_{t}^{\mathbf{k}}=\text { price of coal by consuming class }(\mathbf{k})
\end{aligned}
$$

Foreign demand for West Virginia coal (CDX) is related to the production of steel in the rest of the world (STEELO) and the price of West Virginia coal (CPR).

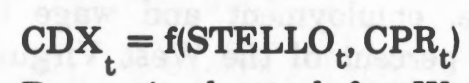

Domestic demand for West Virginia coal (CDD) is determined by summing over the demand regions (i) and over the end users (k).

$$
\mathrm{CDD}_{\mathrm{t}}=\sum_{\mathrm{t}}^{3} \sum_{\mathrm{k}}^{4} \mathrm{CD}_{\mathrm{t}}^{\mathrm{ik}}
$$

Total demand for West Virginia coal (CD) is the sum of domestic coal demand (CDD) and export coal demand (CDX).

$$
\mathrm{CD}_{\mathrm{t}}=\mathrm{CDD}_{\mathrm{t}}+\mathrm{CDX}_{\mathrm{t}}
$$

West Virginia production (CPD) is then estimated from total coal demand (CD) and the changes in West Virginia coal stocks (CDSTK).

$$
\mathrm{CPD}_{\mathrm{t}}=\mathrm{CD}_{\mathrm{t}}+\mathrm{CDSTK}_{\mathrm{t}}
$$

Estimated underground and surface coal production (CPDUE and CPDSE) are then derived from toal coal production

$$
\begin{aligned}
& \mathrm{CPDUE}_{\mathrm{t}}=\left(\frac{\mathrm{CPDU}}{\mathrm{CPD}}\right)(\mathrm{t}-1) \times \mathrm{CPD}_{\mathrm{t}} \\
& \mathrm{CPDSE}_{\mathrm{t}}=\left(\frac{\mathrm{CPDS}}{\mathrm{CPD}}\right)(\mathrm{t}-1) \times \mathrm{CPD}_{\mathrm{t}}
\end{aligned}
$$

Then underground and surface coal supply function (CPDU and CPDS) are estimated as a function of their respected estimated production, and other factors distinguished according to underground versus surface production influence.

$$
\text { CPDU }_{t}=f\left(\text { CPDUE }_{t}, \text { STRIKE }_{t}, \text { CMAHSA }_{t}\right)
$$

where STRIKE is a dummy variable representing the strike year, CMAHSA is a dummy variable representing the passage of the 1969 Coal Mine Health and Safety Act

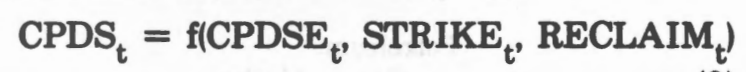

where RECLAIM is a dummy variable reflecting the enforcement of the Reclamation Act of 1977.

Price functions are normally formulated as a function of market excess demand. Although demand factors have historically influenced the price of coal, the overriding causal influence has been the operating costs of coal mines as reflected below in the per employee wage rate (CWR). 


$$
C P R_{t}^{j}=f\left(C W R_{t}^{j}\right)
$$

According to the neoclassical theory, a profit maximizing firm will employ labor until the point is reached at which the value of the marginal revenue of the input (i.e., the marginal product multiplied by the market price of the commodity in question) is exactly equal to the input price (i.e., wage rate). This theory has proved applicable in the West Virginia coal industry where wages (CWR) have been found to depend on labor productivity (CAPL).

$$
\text { CWR }=\mathbf{f}(\mathrm{CAPL})
$$

Labor productivity (CAPL) in West Virginia has been affected by two major factors. First, the passage of the Coal Health and Safety Act of 1969 resulted in an increase in the number of mine employees and operating cost. This increase is shown by the change in the level of employment (DE). Second, scale economies as measured by mine size (CAMS) in both deep and surface mining is also an important deter- minant of labor productivity.

$$
\text { CAPL } \left._{t}^{j}=f_{\left(C^{\prime}\right.} \text { CAMS }_{t}^{j}, D_{t}^{j}\right)
$$

The labor demand function for the West Virginia coal industry is derived from a CobbDouglas production function for this industry. Allowing for a lagged response, the demand for labor (CE) in its final form is related to the level of output (QCL), wage rates (CWR) and one period lagged output.

$$
C D_{t}^{j}=f\left(Q C L L_{t}^{j}, C W R R_{t}^{j}, C E_{t-1}^{j}\right)
$$

The stock of coal is explained by the accelerator principle which states that stocks (CSTK) vary directly with output (CPD); however, stockholding also involves speculative motives related to the price of coal (CPR). Speculative behavior implies a tendency for consumers to guard against rising prices by purchasing additional stocks when price increases are expected, and by reducing stocks when price declines are anticipated.

$$
\operatorname{CSTK}_{t}=f\left(C P D_{t}, C P R_{t}\right)
$$

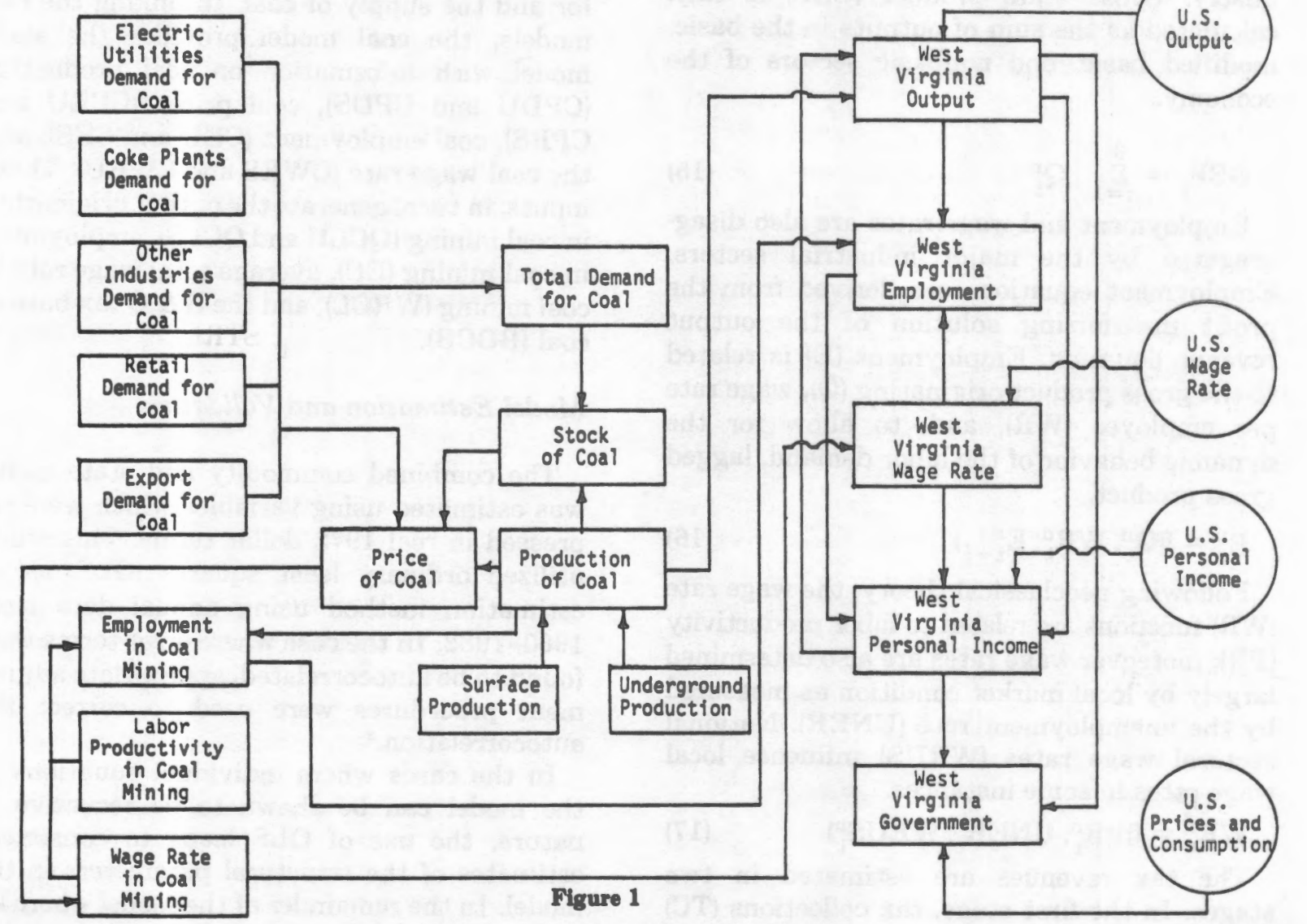

Commodity Regional Annual Macro Model of West Virginia (CREAM Model of West Virginia) 


\section{The State Econometric Model}

The framework of regional production and income accounts provides the basis for the structure of the state econometric model as shown in Figure 1. The basic specification of the model follows generally from that of Adams et al. [1977]. The particular formation that state gross product takes depends on the Niemi [1975] concept of value added by industrial origin while the output structure adopted is based on the modified economic base theory of Isard [1970]. Included in state product are the nine major sectors (n) of the West Virginia economy.

The model begins with output equations for each of the basic sectors. Each equation in this sector relates West Virginia's output to its national counterpart and other explanatory variables. For non-basic sectors, the explanatory variables are local indicators; however, there might also be sectors where their growth depends highly on the growth of the national sector as well as on the growth of local industry. Gross state product (GSP) is then calculated as the sum of outputs in the basic, modified basic, and nonbasic sectors of the economy.

$$
\operatorname{GSP}_{\mathrm{t}}=\sum_{\mathrm{n}=1}^{9} \mathbf{Q}_{\mathrm{t}}^{\mathrm{n}}
$$

Employment and wage rates are also disaggregated by the major industrial sectors. Employment equations are derived from the profit maximizing solution of the output revenue equation. Employment $(\mathbf{E})$ is related to the gross product originating $(Q)$, wage rate per employee (WR), and, to allow for the dynamic behavior of the labor demand, lagged gross product.

$$
E_{t}^{n}=f\left(Q_{t}^{n}, W R_{t}^{n}, E_{t-1}^{n}\right)
$$

Following neoclassical theory, the wage rate (WR) functions are related to labor productivity (PR); moreover wage rates are also determined largely by local market condition as measured by the unemployment rate (UNER). National sectoral wage rates (WRUS) influence local wage rates in some instances.

$$
W R_{t}^{n}=f\left(P R_{t}^{n}, U_{N E R}, W^{\prime} S_{t}^{n}\right)
$$

The tax revenues are estimated in two stages. In the first stage, tax collections (TC) are derived as the product of the appropriate rate (R) and tax base (B).

$$
\mathbf{T C}_{\mathrm{t}}^{\mathrm{m}}=\mathbf{R}_{\mathrm{t}}^{\mathrm{m}} \times \mathbf{B}_{\mathrm{t}}^{\mathrm{m}}
$$

In the second stage, the size of the base is related to the relevant economic activities (Z).

$$
B_{t}^{m}=f\left(Z_{t}^{1}, Z_{t}^{2}, \ldots\right)
$$

In addition to these equations, the model also includes a number of equations based on retail sales, total wage bill, personal income, nonwage income, population, unemployment, etc.

\section{Model Linkages}

The integration of the two independently operating models requires that the variables most essential to providing a bridge between the commodity and state macroeconomic systems be appropriately linked. The West Virginia state econometric model is designed to study the macro relationship between the demand side and the production-employment side of the regional economy. The coal model, by contrast, is very micro in its perspective. It presents a detailed accounting of the demand for and the supply of coal. In linking the two models, the coal model provides the state model with information on coal production (CPDU and CPDS), coal prices (CPRU and CPRS), coal employment (CEU and CES), and the coal wage rate (CWRS and CWRU). These inputs, in turn, generate the output originating in coal mining (QCLU and QCLS), employment in coal mining (EC), average total wage rate in coal mining (WRCL), and the B \& $O$ tax base of coal (BOCB).

\section{Model Estimation and Validation}

The combined commodity and state model was estimated using variables which were expressed in real 1972 dollar terms. This study utilized ordinary least squares (OLS) as an estimation method using annual data from 1960-1982. In the case where error terms were found to be autocorrelated, appropriate adjustment procedures were used to correct the autocorrelation. ${ }^{3}$

In the cases where individual equations in the model can be shown to be recursive in nature, the use of OLS leads to consistent estimates of the structural parameters in the model. In the remainder of the model where individual equations are viewed as being sim- 
ultaneous in nature, it has been established that the use of OLS leads to inconsistent estimates of the structure parameters under the usual assumptions of a correctly specified model.4 On the other hand, the magnitude of the inconsistency may be negligible in actual practice according to World's Proximity Theorem, thereby justifying the use of OLS in modeling simultaneous equations systems. Furthermore, consistency is a large sample property and, at least in this study, may be of little comfort given the sample size of 23 years. Monte Carlo studies of the small sample properties of various single equation and system estimation methods applied to simultaneous equation models are not conclusive regarding the superiority of one method over another. In the case of system estimators such as three stage least squares and full information maximum likelihood, it has been shown that these estimates are less robust in the presence of specification errors than single equation methods. ${ }^{-}$In the case of single equation methods, two stage least squares and limited information maximum likelihood have been favorable compared to OLS in Monte Carlo studies where the estimated model is correctly specified; however, such studies often lead to inconclusive or conflicting results in the presence of specification errors such as omitted variables or erroneous functional form. ${ }^{7}$ To the extent that specification errors are probably present in one or more equations in this study, it was deemed that OLS would not introduce any more bias than other single equation estimation methods.

It has been generally recognized that OLS is an appropriate estimation method in large scale econometric models when the coefficient matrix related to the endogenous variables is sparse, i.e., contains a large number of zeros off the diagonal. In these cases, OLS performance has improved relative to limited information estimation methods as the sample size has increased. ${ }^{8}$ Further indications of the widespread use of OLS is reflected in the number of large scale macroeconometric models which have historically utilized OLS. ${ }^{\circ}$

One final consideration led to the use of OLS, namely computational ease and the degrees of freedom problem. Given the model size in terms of the number of predetermined variables relative to the number of observations, direct application of two stage least squares was impossible since there were more reduced form parameters to estimate than there were observations available. Although the use of two stage least squares with principal components has been proposed to get around the degrees of freedom problem, this method is computationally complex in a model of this size. In addition, this method presumes some acceptable procedure for the selection of the proper number of principal components for inclusion in each model; however, the selection of an improper number will certainly introduce biases in the resulting structural parameter estimates since more or less of the truly endogenous part of the right hand endogenous variable is removed.

There are a variety of statistical tests available for the evaluation of sample period performance of an econometric model. Regarding the comparison of actual and estimated observations, the mean absolute percent error (MAPE), root mean square error (RMSE) or Theil's "U" are those most often employed. It is generally accepted that if the model records a sample MAPE of less than 5-10 percent, then the model's performance is adequate.

Generating the model solutions or simulation values is accomplished by utilizing the values of the model's exogenous variables to generate values of its endogenous variables, the latter then being used as lagged endogenous variables in the simulation. The comparison of the actual and estimated values of the endogenous variables using the MAPE statistic is provided in Table 2 for the key coal industry and state variables. With two exceptions, the errors in these variables are below five percent; more importantly, these figures suggest there is no problem of substantial error build-up or accumulation as the model is solved dynamically over time.

\section{Model Simulation of Changes \\ in Tax Policy and Economic Conditions}

\section{Model Base Forecast}

The model simulations of present interest begin with forecasting beyond the sample period from 1983 to 1985 and feature a model solution under normal or control conditions. That is, the external or exogenous economic variables which represent business activity of the U.S. economy take on values which repre- 
Table 2

Validation of the CREAM Model of West Virginia Mean Absolute Percent Error (MAPE)

1969-1982

\begin{tabular}{lc}
\hline \hline Model Variables & $\begin{array}{c}\text { Mean Absolute } \\
\text { Percent Error }\end{array}$ \\
\hline Gross State Product & 2.2 \\
Total Employment & 0.7 \\
Personal Income & 1.4 \\
Labor Force & 0.7 \\
Total Wage Bill & 1.0 \\
Unemployment Rate & 5.8 \\
Population & 0.7 \\
Total Coal Production & 2.4 \\
Average Coal Price & 7.0 \\
Wage Bill in Coal Mining & 3.4 \\
Total Distribution of WV Coal & 2.1 \\
Total State Revenue & 0.9 \\
Business \& Occupation Tar, Coal & 4.3 \\
\hline \hline
\end{tabular}

Source: Based on the CREAM Model of West Virginia.

Table 3

Model Base Solution: Selocted Indicators

\begin{tabular}{|c|c|c|c|c|}
\hline Variable & 1982 & 1983 & 1984 & 1985 \\
\hline Gross State Product (\$ millions) & $22,116.0$ & $23,725.0$ & $26,376.0$ & $29,264.0$ \\
\hline General Revenue Fund (\$ millions) & $1,265.0$ & $1,167.5$ & $1,252.7$ & $1,350.0$ \\
\hline Total B \& O Tax Collection (\$ millions) & 517.6 & 467.0 & 513.6 & 567.0 \\
\hline Coal-B \& O Tax Collection (\$ millions) & 176.1 & 139.7 & 159.2 & 170.1 \\
\hline Labor Force (thousands) & 741.1 & 747.0 & 749.8 & 755.1 \\
\hline Total Employment (thousands) & 664.8 & 649.1 & 667.3 & 682.6 \\
\hline Unemployment Rate (\%) & 10.3 & 13.1 & 11.0 & 9.6 \\
\hline Population (thousands) & $1,975.0$ & $1,971.0$ & $1,974.0$ & $1,989.0$ \\
\hline Producion of Coal (million tons) & 128.7 & 114.4 & 123.9 & 126.7 \\
\hline Average Coal Price ( $\$$ per ton) & 37.6 & 39.6 & 42.8 & 45.2 \\
\hline \multicolumn{5}{|l|}{ Average Wage Rate } \\
\hline (\$ thousands per employee per year) & 40.5 & 44.1 & 48.4 & 50.6 \\
\hline Employment-Coal (thousands) & 48.0 & 47.2 & 48.9 & 50.3 \\
\hline \multicolumn{5}{|l|}{ Average Productivity of Labor } \\
\hline (tons per man per day) & 10.4 & 10.8 & 10.7 & 10.8 \\
\hline Distribution of Coal, Total (million tons) & 83.9 & 69.9 & 79.2 & 81.7 \\
\hline Electric Utilities (million tons) & 55.8 & 46.7 & 58.3 & 62.0 \\
\hline Coke Plants (million tons) & 19.1 & 14.1 & 11.1 & 9.4 \\
\hline Other Industries (million tons) & 8.5 & 9.1 & 9.8 & 10.3 \\
\hline WV Coal Exports (million tons) & 44.3 & 44.5 & 44.7 & 45.0 \\
\hline
\end{tabular}

sent the best available forecasts for the economy. None of the policy variables or economic variables representing the state of the coal industry are manipulated. The external or exogenous forecasts presently selected for this simulation are based on the April 1983 forecast solution of the Wharton Annual and Industry Model. ${ }^{10}$ This solution assumes growth of the U.S. economy at slightly more than 3 percent over the period which represents a balance between expansion in 1983 of durable goods consumption (7.9 percent) and housing investment (36.0 percent), and a lag until 1984 of recovery in business fixed investment. The results of the CREAM model simulation are reported in Table 3 . Not all of the forecast endogenous variables are included in that table, but only those variables considered to be most important.

Recovery of the West Virginia economy is shown to lag behind that of the national economy. The real gross state product (GSP) is projected to grow by 0.70 percent (compared to the expected growth rate of 3.0 percent for GNP) in 1983; however, the growth rate for GSP will pick up and reach the level of 3.41 
Table 4

Percentage Growth Rate, Output Originating (Real 1972 dollars)

\begin{tabular}{lccc}
\hline \hline Variable & 1983 & 1984 & 1985 \\
\hline Contract Construction & 3.3 & 5.9 & 4.5 \\
Fire & 4.5 & 4.2 & 2.8 \\
Government & 0.0 & 1.5 & 0.7 \\
Manufacturing & & & 5.6 \\
$\quad$ Primary Metal & 2.3 & 6.4 & 2.3 \\
$\quad$ Chemical & 1.0 & 2.4 & 6.0 \\
Mining & & & 2.3 \\
$\quad$ Coal & -9.9 & 2.8 & 4.9 \\
Services & 2.3 & 2.5 & 3.4 \\
TCPU & 4.5 & 5.9 & 3.7 \\
Trade & 12.2 & 3.4 & 3.7 \\
\hline Gross State Product & 0.7 & 3 & \\
\hline \hline
\end{tabular}

and 3.66 percent in 1984 and 1985, respectively. Table 4 demonstrates the percentage growth rate for real output originating in the sectors of the West Virginia economy over the forecast period. It is clear that the main source of growth in 1983 will be trade with output in the wholesale and retail trade sector projected to increase by over 12 percent due to lower interest rates and to consumer optimism. It should be noted that this forecast does not allow for substantial changes in the terms of trade between the United States and major coal customers. Contract construction and primary metal are shown to influence state economic growth more strongly in 1984 and 1985.

The production of coal in West Virginia is forecast to decline by 11.1 percent in 1983 . This decline is due mainly to the high stockpiles of electric utilities, lack of strong demand for domestic steel and cheaper oil prices. However, coal production should increase by 8.3 and 2.3 percent as the stockpile reaches its normal level. It is interesting to note that such an increase is expected to come mostly from electric utilities, since no other coal users show a pronounced increase in their level of demand. Coal exports from West Virginia to Canada and overseas countries show a rather constant trend increase of about $\mathbf{4 5}$ million tons per year through 1985 which is mainly due to the increased competition from other countries, higher cost of transporting coal to overseas countries, and increased substitution of steam coal for West Virginia metallurgical coal production of pig iron.

\section{Changes in Coal Tax Policy}

The coal sector is the leading industry of the West Virginia economy providing the major source of Business and Occupation Tax (B \& O) receipts. The current tax rate for coal (\$3.85 for every $\$ 100$ coal sold) is below most of the other major coal producing states in the United States." In this policy simulation, it is assumed that a new coal tax will be levied first at a rate of $\$ 7$ per $\$ 100$ value of coal in 1983 and secondly at a rate of $\$ 10$ per $\$ 100$. Such increases, if they are absorbed by coal producers, do not have any impact on coal prices, but they do increase the tax collections and add to the total state revenue in 1983 and in later years. For the case where the coal producer is able to shift some of the tax burden to the consumer in the form of price increases, the resulting economic impact is more complicated.

Tables 5 and 6 show the percentage changes in some of the important indicators of the West Virginia economy under this policy simulation. An increase in the tax burden of $\$ 7$ per $\$ 100$ value of coal will result in a decline in coal production of less than 2 percent over the forecast period. By the same token, employment also declines by less than 1 percent. However, the general revenue fund increases by almost 13 percent in 1984 and 1985 . It is possible that the extra income generated can then create jobs to offset any lost jobs in the coal mining sector. The same analysis is also true for an increase in the tax rate on coal to $\$ 10$ per $\$ 100$ value of coal. Even though the losses in production and employment are greater, the gain 
Table 5

Model Simulation: Impact of Coal Tax Rate Increased to $\$ 7.00$ per $\$ 100.00$ Valuea

\begin{tabular}{|c|c|c|c|c|}
\hline Variable & $\begin{array}{c}1982 \\
\text { Base } \\
\text { Values } \\
\end{array}$ & $\begin{array}{c}1983 \\
\text { Percent } \\
\text { Change } \\
\end{array}$ & $\begin{array}{c}1984 \\
\text { Percent } \\
\text { Change }\end{array}$ & $\begin{array}{c}1985 \\
\text { Percent } \\
\text { Chnnge } \\
\end{array}$ \\
\hline Gross State Product $\left(\$ 10^{6}\right)$ & $22,116.0$ & 0.33 & 0.49 & 0.36 \\
\hline General Revenue Fund $\left(\$ 10^{6}\right)$ & $1,265.0$ & 0.08 & 12.81 & 13.47 \\
\hline Total B \& O Tax Collection $\left(\$ 10^{6}\right)$ & 517.6 & 0.16 & 31.44 & 30.85 \\
\hline Coal-B \& O Tax Collection ( $\left.\$ 10^{6}\right)$ & 176.1 & 0.44 & 102.15 & 102.26 \\
\hline Labor Force $\left(10^{3}\right)$ & 741.1 & 0.03 & 0.07 & 0.07 \\
\hline Total Employment $\left(10^{3}\right)$ & 664.8 & 0.04 & 0.10 & 0.11 \\
\hline Unemployment Rate (\%) & 10.3 & -0.20 & -0.45 & -0.39 \\
\hline Population (thousands) & $1,975.0$ & 0.00 & 0.00 & 0.00 \\
\hline Production of Coal (106 tons) & 128.7 & -0.99 & -1.87 & -1.68 \\
\hline Average Coal Price (\$ per ton) & 37.6 & 1.62 & 3.08 & 3.20 \\
\hline Average Wage Rate $\left(\$ 10^{3}\right.$ per employee year) & 40.5 & -0.11 & -0.33 & -0.46 \\
\hline Employment-Coal $\left(10^{3}\right)$ & 48.0 & -0.52 & -0.97 & -0.92 \\
\hline Average Productivity of Labor (tons per man per day) & 10.3 & -0.09 & -0.47 & -0.65 \\
\hline Total Distribution of Coal ( $10^{6}$ tons) & 83.9 & -1.17 & -2.14 & -1.89 \\
\hline Distribution of WV Coal to Electric Utilities ( $10^{6}$ tons) & 55.8 & -1.15 & -2.13 & -1.82 \\
\hline Distribution of WV Coal to Coke Plants ( $10^{6}$ tons) & 19.1 & -0.01 & -0.02 & -0.03 \\
\hline Distribution of WV Coal to Other Industries ( $10^{6}$ tons) & 8.5 & -0.02 & -0.02 & -0.04 \\
\hline WV Coal Exports (106 tons) & 44.3 & -0.67 & -1.28 & -1.25 \\
\hline
\end{tabular}

affective July 1983.

Table 6

Model Simulation: Impact of Coal Tax Rate Increased to $\$ 10.00$ per $\$ 100.00$ Value

\begin{tabular}{|c|c|c|c|c|}
\hline Variable & $\begin{array}{c}1982 \\
\text { Base } \\
\text { Values }\end{array}$ & $\begin{array}{c}1983 \\
\text { Percent } \\
\text { Change }\end{array}$ & $\begin{array}{c}1984 \\
\text { Percent } \\
\text { Chnnso }\end{array}$ & $\begin{array}{c}1985 \\
\text { Percent } \\
\text { Chnnge }\end{array}$ \\
\hline Gross State Product $\left(\$ 10^{6}\right)$ & $22,116.0$ & 0.61 & 0.89 & 0.64 \\
\hline General Revenue Fund $\left(\$ 10^{6}\right)$ & $1,265.0$ & 0.14 & 23.99 & 25.23 \\
\hline Total B \& O Tax Collection $\left(\$ 10^{6}\right)$ & 517.6 & 0.27 & 58.90 & 57.80 \\
\hline Coal-B \& O Tax Collection (\$10 & 176.1 & 0.81 & 191.41 & 191.58 \\
\hline Labor Force $\left(10^{3}\right)$ & 741.1 & 0.08 & 0.12 & 0.20 \\
\hline Total Employment $\left(10^{3}\right)$ & 664.8 & 0.08 & 0.18 & 0.19 \\
\hline Unemployment Rate (\%) & 10.3 & -0.48 & -0.78 & -0.56 \\
\hline Population (thousands) & $1,975.0$ & 0.00 & 0.02 & 0.03 \\
\hline Production of Coal ( $10^{6}$ tons) & 128.7 & -1.76 & -3.36 & -3.15 \\
\hline Average Coal Price (\$ per ton) & 37.6 & 2.78 & 5.92 & 5.97 \\
\hline Average Wage Rate ( $\$ 10^{3}$ per employee year) & 40.5 & -0.21 & -0.62 & -0.87 \\
\hline Employment-Coal $\left(10^{3}\right)$ & 48.0 & -0.96 & -1.78 & -1.67 \\
\hline Average Productivity of Labor (tons per man per day) & 10.3 & -0.09 & -0.75 & -1.30 \\
\hline Total Distribution of Coal (106 tons) & 83.9 & -2.21 & -4.06 & -3.59 \\
\hline Distribution of WV Coal to Electric Utilities (106 tons) & 55.8 & -1.99 & -3.94 & -3.40 \\
\hline Distribution of WV Coal to Coke Plants ( $10^{6}$ tons) & 19.1 & -0.02 & -0.03 & -0.03 \\
\hline Distribution of WV Coal to Other Industries ( $10^{6}$ tons) & 8.5 & -0.07 & -0.08 & -0.09 \\
\hline WV Coal Exports (106 tons) & 44.3 & -1.12 & -2.24 & -2.44 \\
\hline
\end{tabular}

Effective July 1983.

in state revenue is also higher than in the previous case. Therefore, the overall impact of such a coal tax increase would result in a reduction in production and employment, but a drastic increase in state revenues.

\section{Changes in Electricity Generation}

The demand for steam coal is a major factor influencing the West Virginia coal industry and state economy. In this regard, simulations have been conducted of the impact of increases in electricity generation on the state economy. These increases could typically result from several different factors including increased economic recovery, additions to coal-fired generating capacity, or changes in climatic conditions in 1984 and 1985.

Tables 7 and 8 show the industry and 
Table 7

Modal Simulation: Impact Increase in Generation of Blectricity by 6 Percent

\begin{tabular}{|c|c|c|c|c|}
\hline Variable & $\begin{array}{c}1982 \\
\text { Base } \\
\text { Values } \\
\end{array}$ & $\begin{array}{c}1983 \\
\text { Percent } \\
\text { Change }\end{array}$ & $\begin{array}{c}1984 \\
\text { Percent } \\
\text { Change }\end{array}$ & $\begin{array}{c}1985 \\
\text { Percent } \\
\text { Change } \\
\end{array}$ \\
\hline Gross State Product $\left(\$ 10^{6}\right)$ & $22,099.0$ & 0.82 & 0.75 & 0.49 \\
\hline General Revenue Fund $\left(\$ 10^{6}\right)$ & $1,265.0$ & 0.37 & 0.65 & 0.45 \\
\hline Total B \& O Tax Collection (\$10 $)$ & 517.6 & 0.86 & 1.12 & 0.62 \\
\hline Coal-B \& O Tax Collection $\left(\$ 10^{6}\right)$ & 176.1 & 1.00 & 2.03 & 1.58 \\
\hline Labor Force $\left(10^{3}\right)$ & 741.1 & 0.09 & 0.07 & 0.05 \\
\hline Total Employment (103) & 664.8 & 0.12 & 0.11 & 0.10 \\
\hline Unemployment Rate $(\%)$ & 10.3 & -0.59 & -1.01 & -0.78 \\
\hline Population (thousands) & $1,975.0$ & 0.01 & 0.05 & 0.05 \\
\hline Production of Coal (106 tons) & 128.7 & 2.76 & 2.76 & 1.89 \\
\hline Average Coal Price (\$ per ton) & 37.6 & 0.00 & 0.00 & 0.00 \\
\hline Average Wage Rate ( $810^{3}$ per employee year) & 40.5 & 0.98 & 0.95 & 0.64 \\
\hline Employment-Coal $\left(10^{3}\right)$ & 48.0 & 1.41 & 0.94 & 0.49 \\
\hline Average Productivity of Labor (tons per man per day) & 10.3 & 1.66 & 1.68 & 1.21 \\
\hline Total Distribution of Coal ( $10^{6}$ tons) & 83.9 & 4.20 & 4.40 & 2.88 \\
\hline Distribution of WV Coal to Electric Utilities ( $10^{6}$ tons) & 55.8 & 6.82 & 6.56 & 4.28 \\
\hline Distribution of WV Coal to Coke Plants ( $10^{6}$ tons) & 19.1 & 0.00 & 0.00 & -5.35 \\
\hline Distribution of WV Coal to Other Industries ( $10^{6}$ tons) & 8.5 & 0.00 & -1.02 & 0.00 \\
\hline WV Coal Exports ( $10^{6}$ tons) & 44.3 & 0.00 & 0.00 & 0.00 \\
\hline
\end{tabular}

aEffective January 1983.

Table 8

Model Simulation: Impact of Increase in Generation of Electricity by 9 Percent

\begin{tabular}{|c|c|c|c|c|}
\hline Variable & $\begin{array}{c}1982 \\
\text { Base } \\
\text { Values }\end{array}$ & $\begin{array}{c}1983 \\
\text { Percent } \\
\text { Change }\end{array}$ & $\begin{array}{l}1984 \\
\text { Percent } \\
\text { Change }\end{array}$ & $\begin{array}{c}1985 \\
\text { Percent } \\
\text { Change }\end{array}$ \\
\hline Gross State Product $\left(\$ 10^{6}\right)$ & $22,099.0$ & 1.16 & 1.10 & 0.84 \\
\hline General Revenue Fund $\left(\$ 10^{6}\right)$ & $1,265.0$ & 0.52 & 0.92 & 0.73 \\
\hline Total B \& O Tax Collection $\left(\$ 10^{6}\right)$ & 517.6 & 1.17 & 1.68 & 1.09 \\
\hline Coal-B \& O Tax Collection (8106) & 176.1 & 1.50 & 2.90 & 2.47 \\
\hline Labor Force $\left(10^{3}\right)$ & 741.1 & 0.13 & 0.08 & 0.07 \\
\hline Total Employment $\left(10^{3}\right)$ & 664.8 & 0.17 & 0.16 & 0.15 \\
\hline Unemployment Rate (\%) & 10.3 & -0.89 & -1.35 & -1.16 \\
\hline Population (thousands) & $1,975.0$ & 0.02 & 0.07 & 0.08 \\
\hline Production of Coal (10 ${ }^{6}$ tons) & 128.7 & 4.14 & 4.26 & 3.29 \\
\hline Average Coal Price (\$ per ton) & 37.6 & 0.00 & 0.00 & 0.00 \\
\hline Average Wage Rate ( $810^{3}$ per employee year) & 40.5 & 1.41 & 1.33 & 1.07 \\
\hline Employment-Coal $\left(10^{3}\right)$ & 48.0 & 2.00 & 1.33 & 0.87 \\
\hline Average Productivity of Labor (tons per man per day) & 10.3 & 2.31 & 2.33 & 1.95 \\
\hline Total Distribution of Coal ( $10^{6}$ tons) & 83.9 & 6.29 & 6.66 & 4.93 \\
\hline Distribution of WV Coal to Electric Utilities ( $10^{6}$ tons) & 55.8 & 8.99 & 9.69 & 7.24 \\
\hline Distribution of WV Coal to Coke Plants ( $10^{6}$ tons) & 19.1 & 0.00 & 0.00 & 0.00 \\
\hline Distribution of WV Coal to Other Industries ( $10^{6}$ tons) & 8.5 & 0.00 & -1.02 & 0.00 \\
\hline WV Coal Exports (10 $10^{6}$ tons) & 44.3 & 0.00 & 0.00 & 0.00 \\
\hline
\end{tabular}

aEffective January 1983.

economy impacts of increases in electricity generation by 6.0 and 9.0 percent, respectively. In the former case gross state product and the general revenue fund increase by approximately 0.5 percent. However, the coal portion of $\mathbf{B} \& \mathbf{O}$ tax collections rises by as much as 2.0 percent. Coal industry employment as well as the total distribution of coal also increases.

\section{Changes in Pig Iron Production}

An increase in the production of steel and hence of pig iron would result in a rise in demand for metallurgical coal. Demand for metallurgical coal was only 14 percent of total coal demand for West Virginia. Thus, Tables 9 and 10 show only modest state economic im- 
Table 9

Model Simulation: Impact of Increase in Pig Iron Production by 4 Percent

\begin{tabular}{|c|c|c|c|c|}
\hline Variable & $\begin{array}{c}1982 \\
\text { Base } \\
\text { Values } \\
\end{array}$ & $\begin{array}{c}1983 \\
\text { Percent } \\
\text { Change }\end{array}$ & $\begin{array}{c}1984 \\
\text { Percent } \\
\text { Change }\end{array}$ & $\begin{array}{c}1985 \\
\text { Percent } \\
\text { Chnnge }\end{array}$ \\
\hline Gross State Product $\left(\$ 10^{6}\right)$ & $22,116.0$ & 0.11 & 0.11 & 0.12 \\
\hline General Revenue Fund $\left(\$ 10^{6}\right)$ & $1,265.0$ & 0.02 & 0.07 & 0.07 \\
\hline Total B \& O Tax Collection (\$10 $)$ & 517.6 & 0.06 & 0.11 & 0.11 \\
\hline Coal-B \& O Tax Collection (\$106) & 176.1 & 0.19 & 0.29 & 0.32 \\
\hline Labor Force $\left(10^{3}\right)$ & 741.1 & 0.01 & 0.01 & 0.01 \\
\hline Total Employment $\left(10^{3}\right)$ & 664.8 & 0.01 & 0.02 & 0.02 \\
\hline Unemployment Rate (\%) & 10.3 & -0.10 & -0.11 & -0.13 \\
\hline Population (thousands) & $1,975.0$ & 0.00 & 0.00 & 0.00 \\
\hline Production of Coal (106 tons) & 128.7 & 0.38 & 0.45 & 0.50 \\
\hline Average Coal Price (\$ per ton) & 37.6 & 0.00 & 0.00 & 0.00 \\
\hline Average Wage Rate (\$10 $0^{3}$ per employee year) & 40.5 & 0.12 & 0.14 & 0.15 \\
\hline Employment-Coal $\left(10^{3}\right)$ & 48.0 & 0.18 & 0.13 & 0.13 \\
\hline Average Productivity of Labor (tons per man per day) & 10.3 & 0.18 & 0.19 & 0.30 \\
\hline Total Distribution of Coal ( $10^{6}$ tons) & 83.9 & 0.58 & 0.68 & 0.72 \\
\hline Distribution of WV Coal to Electric Utilities (106 tons) & 55.8 & 0.00 & 0.16 & 0.15 \\
\hline Distribution of WV Coal to Coke Plants ( $10^{6}$ tons) & 19.1 & 3.11 & 3.47 & 3.74 \\
\hline Distribution of WV Coal to Other Utilities ( $10^{6}$ tons) & 8.5 & 0.00 & 0.00 & 0.00 \\
\hline WV Coal Exports (10 $10^{6}$ tons) & 44.3 & 0.00 & 0.00 & 0.00 \\
\hline
\end{tabular}

Effective January 1, 1983.

Table 10

Model Simulation: Impact of Increase in Pig Iron Production by 8 Percent

\begin{tabular}{|c|c|c|c|c|}
\hline Variable & $\begin{array}{c}1982 \\
\text { Base } \\
\text { Values } \\
\end{array}$ & $\begin{array}{c}1983 \\
\text { Percent } \\
\text { Change }\end{array}$ & $\begin{array}{c}1984 \\
\text { Percent } \\
\text { Change }\end{array}$ & $\begin{array}{c}1985 \\
\text { Percent } \\
\text { Chango } \\
\end{array}$ \\
\hline Gross State Product $\left(\$ 10^{6}\right)$ & $22,116.0$ & 0.21 & 0.22 & 0.24 \\
\hline General Revenue Fund $\left(\$ 10^{6}\right)$ & $1,265.0$ & 0.05 & 0.13 & 0.15 \\
\hline Total B \& O Tax Collection $\left(\$ 10^{6}\right)$ & 517.6 & 0.08 & 0.21 & 0.24 \\
\hline Coal-B \& O Tax Collection $\left(\$ 10^{6}\right)$ & 176.1 & 0.31 & 0.58 & 0.57 \\
\hline Labor Force $\left(10^{3}\right)$ & 741.1 & 0.02 & 0.01 & 0.02 \\
\hline Total Employment $\left(10^{3}\right)$ & 664.8 & 0.03 & 0.03 & 0.04 \\
\hline Unemployment Rate (\%) & 10.3 & -0.20 & -0.23 & -0.26 \\
\hline Population (thousands) & $1,975.0$ & 0.00 & 0.00 & 0.00 \\
\hline Production of Coal ( $10^{6}$ tons) & 128.7 & 0.84 & 0.95 & 0.98 \\
\hline Average Coal Price (\$ per ton) & 37.6 & 0.00 & 0.00 & 0.00 \\
\hline Average Wage Rate ( $\$ 10^{3}$ per employee year) & 40.5 & 0.26 & 0.27 & 0.35 \\
\hline Employment-Coal $\left(10^{3}\right)$ & 48.0 & 0.36 & 0.26 & 0.27 \\
\hline Average Production of Labor (tons per man per day) & 10.3 & 0.37 & 0.37 & 0.46 \\
\hline Total Distribution of Coal ( $10^{6}$ tons) & 83.9 & 1.28 & 1.42 & 1.44 \\
\hline Distribution of WV Coal to Electric Utilities ( $10^{6}$ tons) & 55.8 & 0.00 & 0.00 & 0.00 \\
\hline Distribution of WV Coal to Coke Plants ( $10^{6}$ tons) & 19.1 & 6.83 & 6.36 & 6.95 \\
\hline Distribution of WV Coal to Other Industries ( $10^{6}$ tons) & 8.5 & 0.00 & 0.00 & 0.00 \\
\hline WV Coal Exports (10 $10^{6}$ tons) & 44.3 & 0.00 & 0.00 & 0.00 \\
\hline
\end{tabular}

Effective January 1, 1983.

pacts, should pig iron production increase at rates of 4.0 percent and 8.0 percent. In the former case, coal distribution to coke plants in. creases approximately 3.5 percent; in the later case the increase is approximately 7.0 percent. The increase in gross state product goes from only 0.1 percent to 0.2 percent with the two production increases.

\section{Conclusions}

The integration of resource commodity and macroeconomic models has been shown to be a very feasible undertaking in the case of coal and the West Virginia economy. In particular, the results suggest that the coal industry and the West Virginia economy were highly inter- 
related with linkages through coal production, coal prices, coal employment, and coal wage rates, among others. Further evidence on the interrelationship was examined through base model simulations as well as simulations of the effects of changes in coal tax policy, electricity generation, and pig iron production. Although the effects on gross state product were not sizable (in terms of percentage changes) in the simulation exercises, the impacts on the state general revenue fund and coal production were substantial in many instances.

Use of an integrated commodity-state econometric model allows the simulation of a wide variety of policy options of interest to public officials and planners. In contrast to some other forecasting approaches, the model structure and assumptions are explicit and can be easily evaluated and understood by the users. Policy variables can be identified and changed in order to simulate the impacts on the endogenous variables in the model. In particular, such a model allows the forecasting of various components of state revenue sources and dimensions of the state economy conditional upon various scenarios regarding the coal sector. In the case of simulations of increases in the B \& $O$ tax on coal, clear evidence of the trade-offs between increased tax revenues and decreased coal production and employment were found. Information on these trade-offs is essential in the determination of the optimal taxation policy for implementation by policy makers.

Although not examined in this study, one can also change the structure of the model to reflect changes in the degree of dependency of the state on one or more commodities. In such a study, for example, one could modify the linkages of the coal sector and the state economy through changes in the magnitude of certain parameters or through the respecification of some endogenous variables as exogenous. Such examinations would allow the simulation of increasing and decreasing dependency of one or more commodities on a state economy. To the extent that policy makers have some control over the developmental prospects of several commodities, such an examination could provide insights into optimal policies, given limited resources, for the development of a state dependent upon multiple commodities.

\section{FOOTNOTES}

'See F. G. Adams and J. R. Behman, Commodity Exports and Economic Development, (Lexington, MA: Heath Lexington Books, 1982).

The West Virginia Business and Occupation Tax is a gross receipts tax with a rate which varies among different business categories. At present the B \& $\mathrm{O}$ tax for coal companies is $\mathbf{3 . 8 5}$ percent of gross receipts.

The appropriate estimation methods included the Cochrane-Orcutt procedure and the Hildreth-Lu procedures. See G. S. Maddala, Econometrics, (New York: McGraw-Hill, 1977), pp. 277-280.

This property has been well documented in many econometrics texts including Madalla, pp. 231.

"See Franklin Fisher, "On the Cost of Approximate Specification in Simultaneous Equation Estimation,"

Econometrica, 29 (April, 1961), pp. 139-170.

'See Jack Johnston, Econometric Methods, (New York: McGraw-Hill, 1984), third edition.

'See Johnston, loc. cit.

'See V. Kerry Smith, Monte Carlo Methods, (Lexington, MA: Lexington Books), 1973 and E. J. Bosbaek and H. O. Wold, eds., Intendependent Systems: Structure and Estimation, (Amsterdam: North-Holland Publishing), 1970.

'See Michael D. Intriligator, Econometric Modele, Techniques and Applications, (New York: Prentice-Hall, 1978), Table 12.12 which surveys major models and their estimation methods.

${ }^{10}$ See Wharton (1983).

"On a percentage basis for example, the West Virginia tax rate is 3.85 percent; Kentucky is 4.5 percent; Wyoming is 4 percent; and Montana is from 3 percent to 30 percent of gross value of coal sold.

\section{REFERENCES}

Adams, F. G. et al. [1977] "On the Specification and Simulation of a Regional Econometric Model: A Model of Mississippi," Journal of Regional Science 17: 161-178.

Adams, F. G. and J. R. Behrman [1982] Commodity Exports and Economic Development (Lexington: D. C. Heath and Co.).

Fisher, F. [1961] "On the Cost of Approximate Specification in Simultaneous Equation Estimation," Econometrica 29: 139-170.

Intriligator, M. D. Econometric Models, Techniguses and Applications (New York: Prentice-Hall, Inc.).

Isard, W. [1970] Methods of Regional Analysis: An Introduction to Regional Science (Bambridge, MA: MIT Press).

Johnson, J. [1981] Econometric Methods, (New York: McGraw-Hill): 139-170.

Labys, W. C. [1973] Dynamic Commodity Models: Specification, Estimation, and Simulation (Lexington: D.C. Heath and Co.).

Labys, W. C. and P. Pollak [1984] Commodity Models for Forecasting and Policy Analysis (London: CroomHelm, Ltd.).

Maddala, G. S. [1977] Econometrics (New York: McGrawHill, Inc.).

Mosbeck, E. J. and H. O. Wold, eds. [1970] Interdependent Systems: Structure and Estimation (Amsterdam: North-Holland).

Niemi, Jr., A. W. [1975] Gross State Product and Productivity in the Southeast (Chapel Hill: The University of North Carolina Press).

Pindyck, R. S. and D. L. Rubenfeld [1981] Econometric Models and Economic Forecasting (New York: 
McGraw-Hill, Inc.).

Shahrokh, F. [1982] "A Commodity-Regional Model of the West Virginia Economy," Ph.D. Dissertation, West Virginia University, Morgantown.

Shahrokh, F. and W. C. Labys [1984] "A CommodityRegional Model of West Virginia," Journal of Regional
Science, forthcoming.

Smith, V. K. [1973] Monte Carlo Methods (Lexington, MA: Heath Lexington Books).

Wharton Econometric Forecasting Associates [1983] "Wharton Long Term Forecasts," WEFA, Philadelphia. 